[Original]

\title{
Short- and Long-term Results of Endoscopic Variceal Ligation for Esophageal Varices Compared with Injection Sclerotherapy
}

\author{
Ikuo Murata, Ichiro YoshiKawa, Keiichiro Kume, Makoto OtsuKi \\ Third Department of Internal Medicine, School of Medicine, University of Occupational and Environ- \\ mental Health, Japan. Yahatanishi-ku, Kitakyushu 807-8555, Japan
}

\begin{abstract}
We assessed the efficacy and safety of endoscopic therapy for esophageal varices in Japanese patients comparing the results of ligation therapy performed in $101 \mathrm{pa}-$ tients with those of sclerotherapy with paravariceal injection of polidocanol in 40 patients. Both therapies were effective in controlling active hemorrhages. Hemostasis rates at the first endoscopic session were $100 \%$ in both groups and rebleeding rates were $40.0 \%$ in the sclerotherapy and $29.6 \%$ in the ligation group. Variceal eradication was achieved equally in both groups in approximately $90 \%$ of the patients. However, the ligation achieved eradication more quickly in fewer endoscopic sessions than did the sclerotherapy (mean; 2.1 vs .3 .7 sessions, $P$ $<0.01$ ). Complications such as rebleeding and intramural hematomas were less common in the ligation group. These results indicate some advantages of the ligation over the sclerotherapy. A disadvantage of the ligation therapy is that recurrence occurs more quickly than in the sclerotherapy, although the difference was not statistically significant.
\end{abstract}

Key words:endoscopic variceal ligation, sclerotherapy, esophageal varices, EVL, EIS.

(Received 16 November 1998, accepted 5 February 1999)

\section{Introduction}

Endoscopic injection sclerotherapy (EIS) has gained wide acceptance as the primary therapy for esophageal varices. It has been shown to improve survival, control active variceal bleeding, and prevent recurrent bleeding $[1,2]$. However, complications are seen in up to $40 \%$ of patients who undergo EIS $[2,3]$. Stiegmann et al. [4, 5] have developed a new procedure of endoscopic treatment, endoscopic variceal ligation (EVL), for esophageal varices that relies on mechanical ligation and strangulation of varices using elastic "O" rings. Since then, several randomized trials have shown that EVL is superior to EIS in the management of patients with bleeding esophageal varices $[6-8]$. These trials were carried out in Western countries and on patients with liver cirrhosis alone, most of whom 
were alcoholics. However, the incidence of the underlying liver disease of esophageal varices varies with geographic location. In an Asian study, Hou et al . [9] conducted a prospective trial on Chinese patients with liver cirrhosis, most of which were etiologically viral, and confirmed superiority of EVl over EIS again. Most patients in Japanese trials, including our study, for esophageal varices have liver cirrhosis secondary to viral hepatitis and a considerable number of the patients develop concomitant hepatocellular carcinoma (HCC).

Since EVL was introduced in Japan in 1990 by Yamamoto et al . [10], there are few English reports documenting detailed results of this technique on Japanese patients. Recently, Kishimoto et al . [11] described the usefulness of EVL in prophylaxis for bleeding from esophageal varices in a trial with Japanese patients. However, there is no published prospective randomized study comparing EIS and EVL in Japan, although Hashizume et al . [12] have described a trial comparing EIS alone with a combination of EVL and EIS.

In our institute, EIS with paravariceal injection of polidocanol had been the primary therapy for esophageal varices until June 1992 when we started EVL. Since then, we have treated a considerable number of patients with EVL. With the increase in number of patients treated, more complications have been encountered than expected in earlier years. The purpose of this study is to assess the short- and long-term efficacy of EVL in 101 patients, by comparing it with that of EIS with polidocanol in 40 patients.

\section{Patients and Methods}

\section{Patients}

Patients with esophageal varices that were bleeding actively (emergency), had bled recently (prophylaxis for rebleeding), or had never bled but showed predictive endoscopic findings for bleeding (prophylaxis for prevention of initial bleeding : primary prophylaxis) were chosen for this study. Patients who were actively bleeding were treated within a few hours of admission. Those in whom bleeding had ceased spontaneously before admission were treated at the earliest opportunity, usually within 24 hours of admission (prophylaxis for rebleeding). Prophylactic endoscopic treatments for initial episodes of bleeding (primary prophylaxis) were performed in the patients whose varices were graded as F2 or F3 in size and shape with positive "red color" (RC) signs such as cherry red spots or hematocystic spots, or F1 varices with high-grade RC signs (definition by the Japanese Research Society for Portal Hypertension [13]). Patients who had an opportunity for treatment between November 1990 and May 1992 underwent EIS, while those between June 1992 and March 1997 received EVL treatment.

\section{Endoscopic Injection Sclerotherapy and Endoscopic Variceal Ligation Techniques}

We used Olympus GIF PQ 20 or GIF Q 200 endoscopes for observation and treatment. Varices were classified and graded according to the general rules for recording endoscopic 
findings of esophageal varices proposed by the Japanese Research Society for Portal Hypertension $[13]$.

EIS was performed with paravariceal injections of $1 \%$ polidocanol. We performed EVL with an endoscopic ligation device and an overtube (Stiegmann and Goff ligator kit ; Bard Interventional Products, Tewksbury, Mass, USA.) from June 1992 to July 1993, then changed to a transparent ligation device (Varioligator kit; Top Co., Tokyo, Japan) because it provides a clearer endoscopic view. Since 1995, we have been using the Pneumo-activate EVL device (Sumitomo-Bakelite Co., Tokyo, Japan). Varices were ligated individually with elastic "O" rings, starting at or near the esophagogastric junction and continuing cephalad to $7-8 \mathrm{~cm}$ above the junction. Three to eight individual ligations were performed at the first session of treatment. All individual varices were ligated at least once per treatment, and large varices were often ligated twice to several times at separate points. Actively bleeding points were ligated first as a rule. According to circumstances, actively bleeding sites, as well as fibrin clots or hematocystic spots, were ligated after ligation of the varices at the esophagogastric junction. EIS and EVL were repeated at 7 -to 14-day intervals until the varices disappeared.

\section{Follow up and recurrence}

After completing the therapy, we repeated the endoscopic examination to assess evidence of recurrent risky varices at 3-month intervals as a rule or for any episode of rebleeding. An appearance of esophageal varices of any size with positive RC signs including teleangiectasia was defined as recurrence.

\section{Statistics}

Student's $t$ test or the Wilcoxon rank-sum test were used for analysis of continuous variables and the chi-square tests or Fisher's exact test for discrete variables. Data were expressed as mean \pm standard error (SE). Kaplan-Meier analysis and the generalized Wilcoxon test were used to examine the time from eradication of the varices to recurrence.

\section{Results}

A total of 141 patients was enrolled in the study ; 40 were in the EIS group and 101 in the EVL group. The characteristics of the two groups are shown in Table 1. Most patients had liver cirrhosis secondary to viral hepatitis. HCC was associated in $35.0 \%$ of the patients in the EIS group and $32.7 \%$ in the EVL group. Active bleeding was found at the first endoscopic session in $25.0 \%$ of the patients in the EIS group and $26.7 \%$ in the EVL group (emergency). Fifteen percent of patients in the EIS group and $12.9 \%$ in the EVL group were defined as a case for prophylaxis against rebleeding, and $60.0 \%$ in the EIS group and $60.4 \%$ in the EVL group were a case for prophylaxis for the initial bleeding (primary prophylaxis). 
Table 1. Characteristics of patients treated by endoscopic injection sclerotherapy or endoscopic variceal ligation

\begin{tabular}{|c|c|c|}
\hline Characteristics & EIS & EVL \\
\hline Patients & $n=40$ & $\mathrm{n}=101$ \\
\hline Mean age $(y r)$ & $55.9 \pm 1.4$ & $56.7 \pm 1.1$ \\
\hline $\operatorname{Sex}(\mathrm{M} / \mathrm{F})$ & $31 / 9$ & $72 / 29$ \\
\hline \multicolumn{3}{|l|}{ Liver disease } \\
\hline Cirrhosis by HBV & 11 & 17 \\
\hline Cirrhosis by HCV & 20 & 74 \\
\hline Alcoholic cirrhosis & 5 & 5 \\
\hline Others & 4 & 5 \\
\hline \multicolumn{3}{|l|}{ Associated lesions } \\
\hline Hepatocellular carcinoma & 14 & 33 \\
\hline Tumor thrombi of portal vein & 2 & 5 \\
\hline \multicolumn{3}{|l|}{ Child-Pugh class } \\
\hline$(\mathrm{A} / \mathrm{B} / \mathrm{C})$ & $16 / 17 / 7$ & $50 / 39 / 12$ \\
\hline Prothrombin time $(\%)$ & $51.4 \pm 4.7$ & $49.5 \pm 3.6$ \\
\hline \multicolumn{3}{|l|}{ Grade of varices } \\
\hline $\begin{aligned} \text { Form } & (\mathrm{F}) \\
& (\mathrm{F} 1 / \mathrm{F} 2 / \mathrm{F} 3)\end{aligned}$ & $2 / 31 / 7$ & $6 / 72 / 23$ \\
\hline $\begin{array}{l}\text { Red Color sign (RC) } \\
\qquad(+/++/+++)\end{array}$ & $9 / 20 / 11$ & $35 / 37 / 29$ \\
\hline $\begin{array}{l}\text { Location }(\mathrm{L}) \\
(\mathrm{Li} / \mathrm{Lm} / \mathrm{Ls})\end{array}$ & $2 / 30 / 8$ & $6 / 76 / 19$ \\
\hline Timing of therapy & & \\
\hline$(\mathrm{E} / \mathrm{PR} / \mathrm{PP}) *$ & $10 / 6 / 24$ & $27 / 13 / 61$ \\
\hline
\end{tabular}

There are no significant differences in patients' characteristics between the two groups.

*E : emergency, PR : prophylaxis against rebleeding, PP : primary prophylaxis.

The two groups did not differ in terms of clinical features, etiology, severity of liver disease (Child-Pugh's class), grade of varices (Form, RC sign and Location), and timing of therapy.

\section{Number of treatments}

One hundred and forty-one treatment sessions of EIS and 521 injections were carried out in 40 patients of EIS group, while 205 sessions of EVL and 857 ligations in 101 patients of EVL group were undertaken. The mean number of sessions per patient was significantly smaller in the EVL group $(3.5 \pm 0.2$ in the EIS group vs $2.0 \pm 0.1, P<0.01)$ (Table 2).

Prophylaxis against recurrent bleeding (prophylaxis for rebleeding)

Prophylactic treatment for rebleeding with EIS was successful during the observation 
Table 2. Results of EIS and EVL

\begin{tabular}{lcc}
\hline & $\begin{array}{c}\text { EIS } \\
(\mathrm{n}=40)\end{array}$ & $\begin{array}{c}\text { EVL } \\
(\mathrm{n}=101)\end{array}$ \\
\hline Number of treatments & & \\
$\quad$ No. of sessions per patient & $3.5 \pm 0.2$ & $2.0 \pm 0.1^{*}$ \\
$\quad$ No. of injections or ligations per patient & $13.0 \pm 1.0$ & $8.5 \pm 0.4$ \\
$\quad$ No. of injections or ligations per session & $3.8 \pm 0.2$ & $4.3 \pm 0.1$ \\
$\quad$ Variceal eradication & $36(90.0)^{\mathrm{a}}$ & $94(93.1)^{\mathrm{a}}$ \\
$\quad$ No. of patients with eradication achieved & $3.7 \pm 0.2$ & $2.1 \pm 0.1^{*}$ \\
$\quad$ Treatment sessions to variceal eradication & & \\
Patients' death & $4(10.0)^{\mathrm{a}}$ & $7(6.9)^{\mathrm{a}}$ \\
$\quad$ Deaths during treatment period & $1(2.5)^{\mathrm{a}}$ & $2(2.0)^{\mathrm{a}}$ \\
\hline Deaths due to bleeding & & \\
\hline
\end{tabular}

Percentages are indicated in parenthesis.

a : percentage to the total patients,

*Indicates significant difference vs EIS $: P<0.01$

periods. EVL was also successful with the exception of one patient who rebled during a treatment period, but additional EVL treatment provided successful hemostasis and variceal eradication.

\section{Primary prophylaxis}

Variceal eradication was achieved in all patients who received primary prophylaxis. Bleeding after eradication occurred in 1 patient in the EIS group and 5 in the EVL group during the observation periods (a mean follow-up duration : 11 months, range ; $2-51$, in the EIS group and 9 months, range ; $2-49$, in the EVL group). There was no significant difference between the two groups. However, the bleeding rates in this study do not accurately indicate prophylactic effects of the treatments, because most of the recurrent varices were treated again with EIS or EVL when they showed endoscopic signs of risky varices. Therefore, the prophylactic effect was evaluated later in the paragraph titled "Recurrence of esophageal varices", dealing together with patients who bled and those who underwent prophylactic endoscopic retreatment.

\section{Variceal eradication}

Variceal eradication was achieved in $90.0 \%$ of the patients in the EIS group and $93.1 \%$ in the EVL group; the difference was not significant. It was achieved, however, in fewer endoscopic sessions in the EVL group than in the EIS group (mean ; 2.1 vs. $3.7, \mathrm{P}<0.01$ ). Variceal obliteration was not achieved in 4 patients in the EIS group and 7 in the EVL group because of death during the index hospitalization (Table 2). In general, varices that were larger in size, showed severer RC signs or higher location, and were associated with severer 
Table 3. Results in emergency cases

\begin{tabular}{ccc}
\hline & $\begin{array}{c}\text { EIS } \\
(\mathrm{n}=10)\end{array}$ & $\begin{array}{c}\text { EVL } \\
(\mathrm{n}=27)\end{array}$ \\
\hline Hemostasis for active bleeding & & \\
Active bleeding at initial treatment & $10(25.0)^{\mathrm{a}}$ & $27(26.7)^{\mathrm{a}}$ \\
Hemostasis achieved at the first treatment & $10(100)^{\mathrm{b}}$ & $27(100)^{\mathrm{b}}$ \\
Recurrent bleeding during treatment periods & $4(40.0)^{\mathrm{b}}$ & $8(29.6)^{\mathrm{b}}$ \\
\hline
\end{tabular}

Percentages are indicated in parenthesis.

a : percentage to the total patients,

$\mathrm{b}:$ percentage to the patients with active bleeding.

There is no significant difference between both groups.

liver disease (Child-Pugh class B or C) required more treatment sessions (data are not shown).

\section{Hemostasis in an emergency}

In the emergency cases (10 patients in the EIS group and 27 patients in the EVL group), hemostasis was achieved at the first treatment session in all patients with actively bleeding in each group. Bleeding, however, recurred in $40.0 \%$ of the patients in the EIS group and 29.6 $\%$ in the EVL group during the index hospitalization, although the difference was not significant (Table 3). Most of these patients who rebled had severe liver dysfunction graded as Child-Pugh class B or C. Hemostasis was achieved again by the endoscopic treatments in 3 of the 4 patients in the EIS group and in 5 of the 8 in the EVL group. One patient in the EIS group and 2 in the EVL group died of exsanguination in spite of additional treatments such as repeated EIS or EVL, and balloon tamponade.

\section{Recurrence of esophageal varices}

Excluding patients who died during the treatment periods, 36 patients in the EIS group and 94 in the EVL group were followed up by endoscopic examination, with a mean followup period of 8 months (range ; $2-51$ ) in the EIS group and 9 months (range ; $2-49$ ) in the EVL group. Recurrence rates at 1 and 3 years were $28.8 \%$ and $57 \%$, respectively, in the EIS group, and $31.7 \%$ and $76.5 \%$, respectively, in the EVL group. However, the length of time from variceal eradication to recurrence was not significantly different between the two groups (Fig. 1). In the patients who underwent primary prophylactic treatments, recurrence rates at 1 and 3 years were $25.7 \%$ and $60.4 \%$, respectively in the EIS group $(n=24)$, while they were $31 \%$ and $80.8 \%$ in the EVL group $(n=61)$. Kaplan-Meier estimation showed no significant difference between the two groups (Fig. 2)

Risky varices or variceal bleeding appeared to recur more quickly in the EVL group than in the EIS group, though the difference was not statistically significant. A total of 48 pa- 


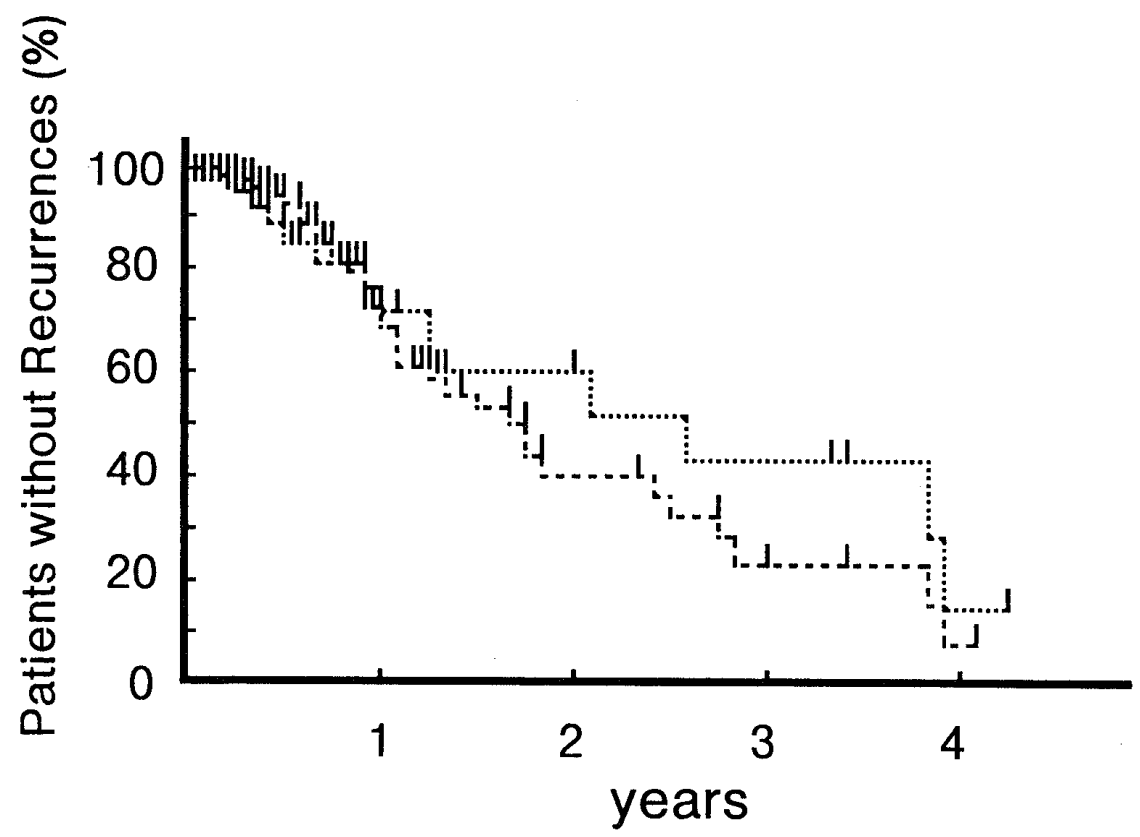

Fig. 1. Kaplan-Meier curves for absence of recurrence of risky varices or bleeding after variceal eradication. The difference between the two groups is not statistically significant.

$$
\operatorname{EIS}(\mathrm{N}=36)
$$
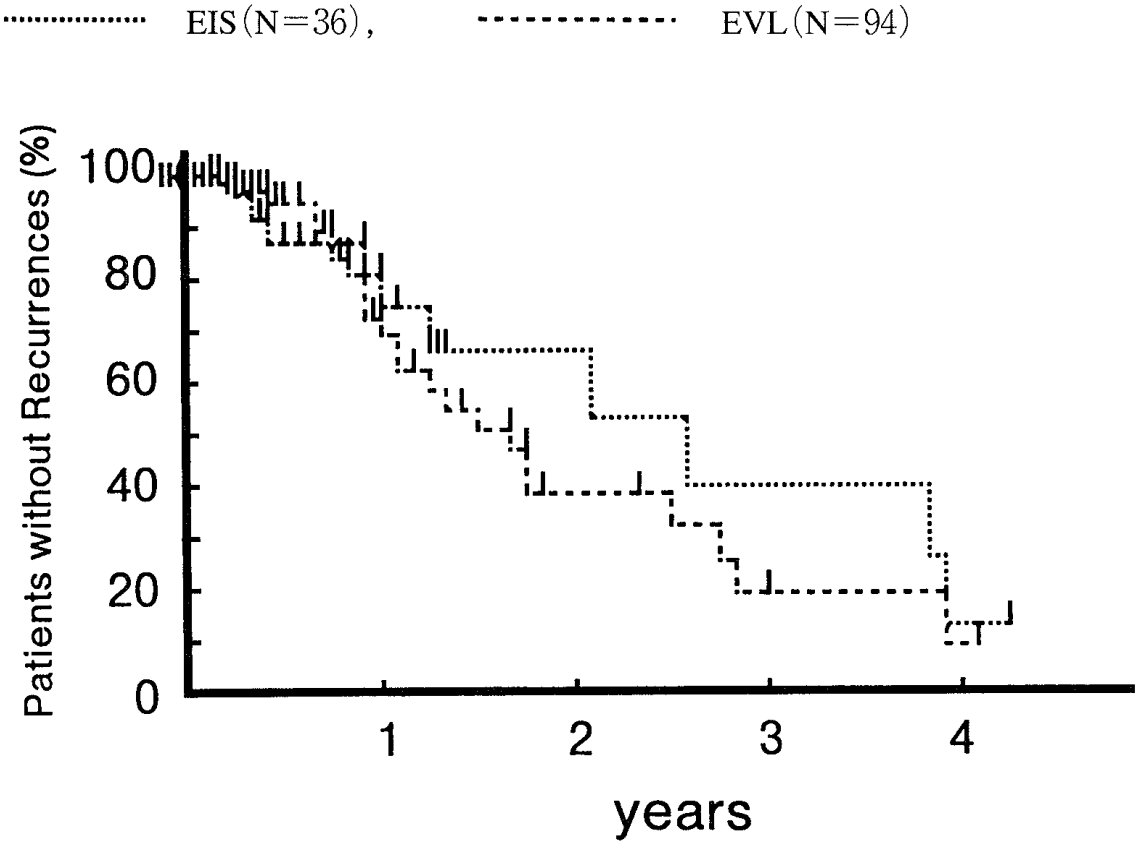

Fig. 2. Kaplan-Meier curves for absence of recurrence of risky varices or bleeding after variceal eradication in patients who underwent prophylactic treatments. The difference between the two groups is not significant.

$$
\operatorname{EIS}(\mathrm{N}=24)
$$

tients underwent follow-up studies beyond one year from the variceal eradication by EVL. To determine factors having an influence on early recurrence, characteristics of patients who had developed recurrent risky varices or bled within 1 year of eradication $(n=15)$ were compared with those of patients who were free from the recurrence within 1 year $(n=33)$ (Table 
Table 4. Characteristics of 48 patients who were followed up for more than 1 year from variceal eradication by EVL; a comparison between patients with or without recurrence of risky varices or bleeding within 1 year of the eradication

\begin{tabular}{|c|c|c|}
\hline Characteristics & $\begin{array}{l}\text { Recurrence } \\
\text { within } 1 \text { year }\end{array}$ & $\begin{array}{c}\text { Free of recurrence } \\
\text { within } 1 \text { year }\end{array}$ \\
\hline Patients & $\mathrm{n}=15$ & $\mathrm{n}=33$ \\
\hline Mean age $(\mathrm{yr})$ & $51.7 \pm 3.2$ & $55.9 \pm 2.0$ \\
\hline $\operatorname{Sex}(M / F)$ & $12 / 3$ & $22 / 11$ \\
\hline \multicolumn{3}{|l|}{ Liver disease } \\
\hline Cirrhosis by HBV & 2 & 3 \\
\hline Cirrhosis by HCV & 11 & 24 \\
\hline Alcoholic cirrhosis & 1 & 4 \\
\hline Others & 1 & 2 \\
\hline $\begin{array}{c}\text { Associated HCC } \\
(-/+)\end{array}$ & $11 / 4$ & $21 / 12$ \\
\hline $\begin{array}{l}\text { Child-Pugh class } \\
\qquad(\mathrm{A} / \mathrm{B} / \mathrm{C})\end{array}$ & $6 / 5 / 4$ & $19 / 12 / 2$ \\
\hline $\begin{array}{l}\text { Grade of varices } \\
\qquad \begin{array}{r}\text { Form }(\mathrm{F}) \\
(\mathrm{F} 1 / \mathrm{F} 2 / \mathrm{F} 3)\end{array}\end{array}$ & $1 / 7 / 7 *$ & $8 / 20 / 5^{*}$ \\
\hline $\begin{array}{l}\text { Red Color sign }(\mathrm{RC}) \\
\qquad(+/++/+++)\end{array}$ & $3 / 4 / 8$ & $12 / 12 / 9$ \\
\hline $\begin{array}{l}\text { Location }(\mathrm{L}) \\
(\mathrm{Li} / \mathrm{Lm} / \mathrm{Ls})\end{array}$ & $1 / 9 / 5$ & $3 / 27 / 3$ \\
\hline \multicolumn{3}{|l|}{ Timing of therapy } \\
\hline \multicolumn{3}{|l|}{ Treatment } \\
\hline No. of sessions to eradication & $2.5 \pm 0.2 *$ & $1.9 \pm 0.1 *$ \\
\hline No. of ligation to eradication & $9.8 \pm 0.8^{*}$ & $7.0 \pm 0.5^{*}$ \\
\hline
\end{tabular}

* : Statistically significant $(P<0.05)$

** : Timing of therapy; E : emergency, PR : prophylaxisi against rebleeding, PP : primary prophylaxis.

4). Size of varices $(\mathrm{F} 1 / \mathrm{F} 2 / \mathrm{F} 3)$ was significantly different between the two groups ; varices were larger in the former. Furthermore, the former likely included severer RC signs and highly extended varices (Ls), although the differences were not significant. Consequently, the former required more sessions and ligations to eradicate varices.

\section{Complications}

Except for the patients who died or deteriorated severely soon after admission, there were no significant changes in general conditions and in the laboratory data in both groups

(Table 5). A summary of complications is shown in Table 6. Fewer complications were seen in the EVL group $(12.9 \%)$ than in the EIS group $(32.5 \%)(P<0.05)$. The most com- 
Table 5. Changes in laboratory data after EIS or EVL

\begin{tabular}{lcrrrrr}
\hline \multirow{2}{*}{ Laboratory test } & \multirow{2}{*}{$\begin{array}{c}\text { Normal } \\
\text { range }\end{array}$} & \multicolumn{2}{c}{ Before } & \multicolumn{1}{c}{ After } & & \multicolumn{2}{c}{$\operatorname{EVL}(\mathrm{n}=74)$} \\
\cline { 6 - 7 } \cline { 6 - 7 } & \multicolumn{1}{c}{ Before } & \multicolumn{1}{c}{ After } \\
\hline Total Bilirubin & $0.2-1.0 \mathrm{mg} / \mathrm{dl}$ & $1.4 \pm 0.1$ & $1.2 \pm 0.1$ & & $1.5 \pm 0.2$ & $1.4 \pm 0.2$ \\
Albumin & $4.0-5.4 \mathrm{~g} / \mathrm{dl}$ & $3.2 \pm 0.1$ & $3.3 \pm 0.1$ & & $3.3 \pm 0.1$ & $3.4 \pm 0.1$ \\
GPT & $-40 \mathrm{IU} / \mathrm{I}$ & $59.4 \pm 6.8$ & $61.3 \pm 10.2$ & & $64.3 \pm 8.0$ & $57.5 \pm 6.4$ \\
ALP & $3.2-10.4 \mathrm{KAU}$ & $11.5 \pm 1.2$ & $10.5 \pm 0.9$ & & $11.6 \pm 0.9$ & $11.9 \pm 1.2$ \\
Choline esterase & $275-724 \mathrm{IU} / \mathrm{I}$ & $199.7 \pm 13.8$ & $205.8 \pm 13.4$ & $242.7 \pm 15.9$ & $230.6 \pm 14.7$ \\
Hemoglobin & $11.3-17.7 \mathrm{~g} / \mathrm{dl}$ & $11.2 \pm 0.4$ & $111.2 \pm 0.3$ & & $11.5 \pm 0.3$ & $11.6 \pm 0.4$ \\
Platelet & $14.4-38.0 \times 10^{4} / \mathrm{mm}^{3}$ & $8.4 \pm 0.6$ & $8.6 \pm 0.8$ & $7.9 \pm 0.9$ & $7.7 \pm 0.7$ \\
\hline
\end{tabular}

There are no significant differences in laboratory data before and after treatments in both groups.

Table 6. Complications

\begin{tabular}{|c|c|c|}
\hline \multirow{2}{*}{ Complicatious } & EIS & EVL \\
\hline & $(n=13)(32.5)$ & $(\mathrm{n}=13) *(12.9)$ \\
\hline Bleeding & $7(17.5)$ & $8 *(7.9)$ \\
\hline Intramural hematoma & $5(12.5)$ & $1 *(1.0)$ \\
\hline Esophageal stricture & $2 \quad(5.0)$ & $1 \quad(1.0)$ \\
\hline Severe chest pain & $2 \quad(5.0)$ & $0 \quad(0.0)$ \\
\hline Pleural effesion & $3(7.5)$ & $2(2.0)$ \\
\hline Pneumonia & $1 \quad(2.5)$ & $1 \quad(1.0)$ \\
\hline Fever & $1 \quad(2.5)$ & $0 \quad(0.0)$ \\
\hline Mesenteric venous thrombosis & $0 \quad(0.0)$ & $1 \quad(2.4)$ \\
\hline
\end{tabular}

Percentages to patients in each group are indicated in parenthesis.

*Indicates significant difference vs EIS $(P<0.05)$.

mon complication in both groups was bleeding which occurred in $17.5 \%$ of the patients in the EIS group and $7.9 \%$ in the EVL group $(P<0.05)$. Intramural hematoma of the esophagus was seen in $12.5 \%$ in the EIS group and in $1.0 \%$ in the EVL group $(P<0.05)$. Esophageal stricture with a complaint of dysphagia was seen in 2 patients in the EIS group and 1 in the EVL group, who required a treatment with pneumatic balloon dilatation.

Although many patients in both groups complained of retrosternal pain or discomfort in varying degrees within a few days of the treatment, severe chest pain was seen only in the EIS group. Pulmonary complications were seen in both groups. Three patients in the EIS group and 2 in the EVL group developed pleural effusion. In 2 of the 3 patients in the EIS group, the effusion appeared within 1 or 2 days of the treatment with severe chest pain and inflammatory reactions in the laboratory data, indicating the association of mediastinitis, whereas in the EVL group, the pleural effusion developed later after the treatment, indicating no relation to mediastinitis. Superior mesenteric vein thrombosis, resulting in ischemic ile- 
itis with massive melena, occurred in a patient with idiopathic portal hypertension 4 months after EVL therapy [14]. She was treated conservatively without surgery and recovered with the disappearance of the thrombosis.

\section{Discussion}

This study showed that EVL has significant advantages over EIS. Although both therapies were equally effective in hemostasis for active bleeding and variceal eradication, statistical differences in favor of EVL were noted in the number of treatment sessions required for variceal eradication and the incidence of complications. We found that EVL required 1.6 fewer treatment sessions to achieve the eradication than EIS, which is similar to that reported in Western countries $[6-8]$.

It has also been emphasized that EVL is safer than EIS. Nakase et al . [15] reported that EVL causes no significant changes in hepatic and renal function, whereas deterioration of liver function tests are observed in patients who underwent EIS. In the present study, both EIS and EVL did not have any influence on laboratory data of the patients. This discrepancy between the previous and present studies may be due to the differences in the procedure of injection (intra-or paravariceal) and sclerosants used (ethanolamine oleate or polidocanol). As well as EVL, EIS with paravariceal injection appears to be safer than with intravariceal injection.

Our study showed that EVL had a significantly lower complication rate than EIS (EVL $12.9 \%$ vs. EIS $32.5 \%, P<0.05)$. Complication rates are considerably different among the studies in the literature. These discrepancies may be due to differences among the trials in design (multicenter or single center), the incidence and proportion of underlying liver diseases, and the definition of complications. We defined rebleeding as a complication but excluded esophageal ulcer from complications because it is an almost inevitable consequence of both EVL and EIS with paravariceal injection used in our study. If rebleeding were excluded, the complication rate in the EVL group would be similar to that reported by Stiegmann et al. [6].

Although EVL is accepted as a safe technique, several new complications are found with an increase in the number of patients treated. In our institute, no pulmonary complication was found in the EVL group in the early years, but the present study showed that pleural effusion and aspiration pneumonia occurred in $1-2 \%$ of the patients. It is notable that the cardiopulmonary complications can be associated even with EVL. Iwao et al . [16] reported that oxygen desaturation and cardiac arrhythmia are common in patients undergoing EVL, and advised supplemental oxygen to avoid cardiopulmonary accidents.

The efficacy of EIS in preventing initial episodes of bleeding (primary prophylaxis) and inproving survival among such patients still remains controversial. In published trials comparing prophylactic sclerotherapy with no treatment, the number of bleeding episodes is 
found to be reduced in some studies $[17,18]$, not reduced or increased in others $[19,20]$. A recent study showed that propranorol, rather than EIS or EVL, is the only cost-effective form of prophylactic therapy for preventing initial bleeding in cirrhosis [21]. The present study revealed that prophylactic EIS and EVL are equally effective in preventing initial bleeding during the observation periods.

A prospective randomized study showed that recurrence of varices appears more probable with EVL than EIS with intravariceal injection [9]. The present study revealed that the time to the recurrence was not different between the therapies by Kaplan-Meier estimation. The reason for this may be due to the procedure of EIS with paravariceal injection used in this study, in which the eradication effect of the varices is not so complete as in intravariceal injection. Intravariceal injection can occlude feeding vessels to varices from the portal system, while paravariceal injection affects vessels only in the superficial parts of the esophageal wall. In fact, however, recurrence rates at 1 and 3 years were higher in the EVL group. We likewise feel that the most inportant disadvantage of EVL is early recurrence. Therefore, prevention of early recurrence is crucial. There are a few additional procedures to prolong the eradication effect of EVL. Octreotide, a synthetic analogue of somatostatin, is shown to reduce recurrent bleeding after EVL [22]. Since EVL alone has not provided satisfactory results regarding to long-term prophylaxis, a combination of EVL and EIS with polidocanol is recommended to provide more complete eradication of varices, leading to prevention of the recurrence with fewer complications than the EIS alone [23]. Therefore, we are performing this combination therapy at present.

In conclusion, both EIS and EVL are equally effective in controlling active variceal bleeding, eradication of varices, and presumably for primary prophylaxis. EVL is superior to EIS in respect to a lower incidence of complications, an easier technique of the treatment and fewer endoscopic sessions for achieving variceal eradication. The disadvantage of EVL is a relatively higher recurrence rate and earlier recurrence of risky varices. Further studies are necessary to seek for additional techniques to overcome the disadvantages.

\section{References}

1. Paquet KF, Kalk JF \& Koussouris P (1988) : Immediate endoscopic sclerosis of bleeding esophageal varices : a prospective evaluation over five years. Surg Endosc 2: $18-23$

2. Infante-Rivard C, Esnaola S \& Villeneuve JP (1989)： Role of endoscopic variceal sclerotherapy in the long-term management of variceal bleeding : a meta-analysis. Gastroenterology $96: 1087-$ 1092

3. Schuman BM, Beckman JW, Tedesco FJ et al (1987) : Complications of endoscopic injection sclerotherapy : a review. Am J Gastroenterol 82: 823-830

4 . Stiegmann GV, Cambre T \& Sun JH (1986) : A new endoscopic elastic band ligating device. Gastrointest Endosc 32: 230-233 
5 . Stiegmann GV, Goff JS, Sun JH et al (1990) : Endoscopic ligation of esophageal varices. Am J Surg 159: $21-26$

6. Stiegmann GV, Goff JS, Michaletz-Onody PA et al (1992) : Endoscopic sclerotherapy as compared with endoscopic ligation for bleeding esophageal varices. N Engl J MEd 326: 1527-1532

7 . Laine L, El-Newihi HM, Migikovsky B et al (1993) : Endoscopic ligation compared with sclerotherapy for the treatment of bleeding esophageal varices. Ann Intern Med 119: 1-7

8. Gimson AES, Ramege Jk, Panos MZ et al (1993) : Randomised trial of variceal banding ligation versus injection sclerotherapy for bleeding esophageal varices. Lancet 342: 391-394

9 . Hou MC, Lin HC, Kuo BIT et al (1995) : Comparison of endoscopic variceal injection sclerotherapy and ligation for the treatment of esophageal variceal hemorrhage : a prospective randomized trial. Hepatology 21: 1517-1522

10. Yamamoto M, Suzuki H, Aoki T et al (1990) : Endoscopic variceal ligation (EVL) Shoukakinaishikyou (Endoscopia Digestiva) 2: 269-275 (in Japanese with English abstract)

11. Kishimoto H, Sakai M, Kajiyama T et al (1997) : Clinical trial of prophylactic endoscopic variceal ligation for esophageal varices. J Gastroenterol - 32: 6-11

12. Hashizume M, Ohta M, Ueno K et al (1993) : Endoscopic ligation of esophageal varices compared with injection sclerotherapy : a prospective randomized trial. Gastrointest Endosc 39 : 123-126

13. Japanese Research Society for Portal Hypertension (1992) : The general rules for recording endoscopic findings on esophageal varices (1991). Acta Hepatol Jpn 33 : 277-281

14. Tachibana I, Yoshikawa I, Sano Y et al (1995) : A case of mesenteric venous thrombosis after endoscopic variceal ligation. J Gastroenterol $30: 254-257$

15. Nakase H, Kawasaki T, Komori H et al (1996) : Endoscopic variceal ligation versus endoscopic injection sclerotherapy : comparison of hepatic and renal function. Am J Gastroenterol 91: 21702173

16. Iwao T, Toyonaga A, Shigemori H et al (1995) : Supplemental oxygen during endoscopic variceal ligation : effects on arterial oxygenation and cardiac arrhythmia. Am J Gastroenterol 90 : 21862190

17. Witzel L, Wolbergs E \& Herki H (1985): Prophylactic endoscopic sclerotherapy of esophageal varices. Lancet 1: $773-775$

18. The Veterans Affairs Cooperative Variceal Sclerotherapy Group (1991): Prophylactic sclerotherapy for esophageal varices in men with alcoholic liver disease. A randomized, single-blind, multicenter clinical trial. N Engl J Med 324 : 1779-1784

19. Sauerbruch T, Wortzka R, Kopcke W et al (1988) : Prophylactic sclerotherapy before the first episode of variceal hemorrhage in patients with cirrhosis. N Engl J Med 319: 8-15

20. Santangelo WC, Dueno MJ, Estes BL et al (1988) : Prophylactic sclerotherapy of large esophageal varices. N Engl J Med 318: 814-818

21. Teran JC, Imperiale TF, Mullen KD et al (1997) : Primary prophylaxis of variceal bleeding in cirrhosis : A cost-effectiveness analysis. Gastroenterology 112: 473-482

22. Sung JJY, Sydney Chung SC, Yung MY et al (1995) : Prospective randomised study of effect of oc- 
treotide on rebleeding from oesophageal varices after endoscopic ligation. Lancet $346: 1666-$ 1669

23. Suzuki H, Chibai M, Yamamoto M et al (1996) : Present status of endoscopic therapy for esophageal varices -endoscopic variceal ligation(EVL) -. Nihon Geka Gakkai Zasshi (J Jpn Surg Soc) 97 : 49-54 (in Japanese with English abstract)

食道静脈瘤に対する内視鏡的静脈瘤結紮術の短期および長期成績 一硬化療法との比較一

村田 育夫, 芳川一郎, 久米恵一郎, 大梘畺

産業医科大学医学部 第三内科学教室

要旨：日本人患者の食道静脈瘤に対する内視鏡的静脈瘤結柏術（対象101名）と polidocanol の傍静脈瘤注入による硬化療法（対象40名）の有効性と安全性を比較検討した，止 血率は両群で $100 \%$ であり, 再出血は硬化療法で $40.0 \%$ 、結紫療法で $29.6 \%$ あった。 静脈瘤の根絶は両群とも同様に約 $90 \%$ の患者で得られた。しかし, 結禁療法では硬 化療法より迅速に根絶が成し遂げられた（平均； $2.1: 3.7, P<0.01)$. 再出血や壁内 血腫などの合併症は結紮療法で少なかった。これらの結果は結紮療法の方が有用性 が幾分高いことを示している．結紮療法の欠点は硬化療法より再発が早いことであ るが, 統計的には有意差はなかった。

$$
\text { J UOEH（産業医大誌）21（2）:119-131（1999） }
$$

